\title{
免疫学的にみた気管支喘息の治癒と寛解予知
}

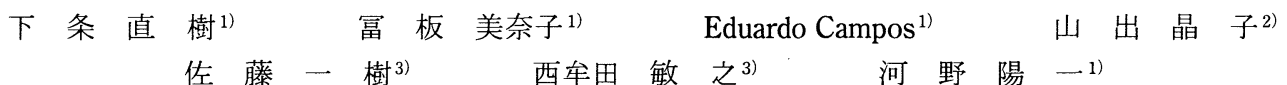

千葉大学大学院医学研究院小児病態学 ${ }^{1)}$, 千葉県こども病院アレルギー科 ${ }^{2)}$, 独立行政法人国立病院機構下志津病院小児科 ${ }^{3)}$

key words : 小児喘息，寛解，制御性（抑制性）T細胞，サイトカイン

はじめに

小児気管支喘息には寛解・治癒が存在することが知 られているが，その機序は十分に解明されていない. 小児気管支喘息治療・管理ガイドライン 2002 において, 治瘉の定義には症状のみでなく肺機能，気道過敏性試 験の正常化も含まれている．興味深いことに，ここに は全くアレルギー反応の検査に関する記載はない，す なわち，アレルゲン感作の状態（たとえばアレルゲン 特異 $\operatorname{IgE}$ 値）は寛解・治癒には直接的には関与しない ことを示唆している.

一方，小児の気管支喘息の大部分がアトピー型であ り，大部分の気管支喘息患者がダニに感作されている こと，食物アレルゲンやダニアレルゲンへの早期の感 作がその後の喘息の発症に関連すること ${ }^{1)}$ ，などから アレルゲンへの免疫応答性が気管支喘息の病態に関 わっていることは確かと考えられる．本稿では，小児
喘息の寛解・治癒とアレルゲンへの免疫応答性の関連 について我々のデータも含めて考えてみたい.

\section{喘息活動性と特異 lgE，Th2サイトカイン}

喘息の病態には，先に述べたように肺機能と気道過 敏性がきわめて重要である。では，これらと免疫学的 な指標には関連があるのだろうか? Visserらはステロ イド吸入によって安定していた喘息患者において吸入 ステロイド薬を中止した後に気道過敏性を獲得した群 と気道過敏性がなかった群における各種のパラメー ター值を比較している，その結果，気道過敏性を有す る群では, 血清総 $\operatorname{IgE}$ 值, RASTの陽性率, 室内塵ダ 二（HDM）特異 IgE 陽性率が有意に高い結果であった 2).さらにドイツでの乳児期からのコホート研究でア レルゲンへの感作と喘息, 喘鳴, 気道過敏性に強い相 関があることが明らかとなっている3）(図 1)。以上の 結果はアレルゲンへの感作は気道過敏性を充進させて
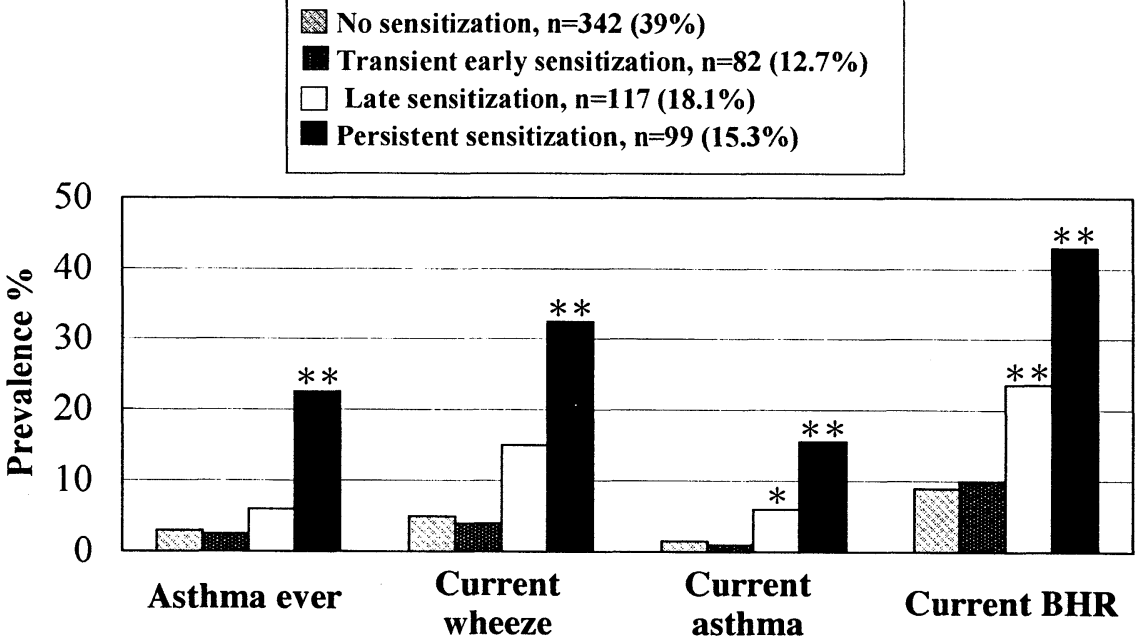

文献 3 より

図 1. アレルゲン感作と喘息・気道過敏性の関連 
喘息発症に深く関与していることを示している. また Cho らは，喘息患者での気道過敏性と肺胞気管洗浄液 中のサイトカイン産生細胞を比較し, 気道過敏性の強 さと IL-4, IL-5 産生細胞の割合が相関することを報告 している4). 以上からアレルギー反応に重要な $\mathrm{Th} 2$ サイ トカインならびにアレルゲン特異 $\operatorname{IgE}$ 抗体の高值が気 道過敏性・喘息重症度と関連することが強く示唆され る(図2).

\section{喘息寛解とダニ特異 $\lg E$ 抗体值, Th2 サイトカイン}

上記のように喘息の活動性にタイプ 2 免疫応答が関 与するならば，気道過敏性の低下，喘息の寛解に Th2 サイトカインの産生量やアレルゲン特異 IgE抗体值の

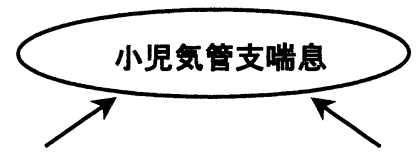

アトピー秦因

免疫細胞側の

因子

\section{タイプ2免度応管}

気道過敏性

気道上皮、気道平滑筋 側の因子

リモデリング関連分子

図2. アレルギー反応と気道過敏性の関連

変化が関連する可能性がある．しかしながらそのよう な検討は我々の調べた限りでは十分になされていない. そこで，小児期から数年以上にわたり千葉大および関 連病院に通院しており思春期に達している気管支喘息 患者を対象として，気管支喘息の活動性が低下してい る群と非軽快群での数年間のコナヒョウヒダニ特異 $\mathrm{IgE}$ 值の推移を解析した. すると軽快群では大部分の 患者でダ二特異 $\operatorname{IgE}$ 值が経年的に減少しているのに対 し, 非軽快群では多くの患者でRAST值が 100 以上のま まか 100 以下であっても減少傾向にないことがわかっ た（図3）。また思春期をこえて寛解にいたった患者と 活動性が高く継続的な治療を必要としている患者を対 象として血清総 IgE 值とコナヒョウヒダニ特異 $\operatorname{IgE}$ 值 を比較すると, 寛解群においては非寛解群よりも, 有 意差はないものの血清 $\operatorname{IgE}$ 值が低く, 特異 $\operatorname{IgE}$ は有意に 低值であった (図4).これらの結果から, 寛解しやす い患者は経時的に特異 IgE 值が低下してくる可能性が あると考えられる. アレルギー性鼻炎についてもアレ ルゲン特異 IgE抗体值が低いほど宽解しやすいことが 最近報告されている ${ }^{5)}$. Th2 タイプのサイトカインであ るIL-5のダニアレルゲン刺激による末梢血単核球から の産生能を先の寛解・非寛解の患者群で比較してみる と, 寛解群で有意にIL-5 産生細胞数が少ない（図 5). 以上から喘息の寛解に $\mathrm{Th} 2$ サイトカインの産生低下が 関与することが示唆される.

\section{軽快群}

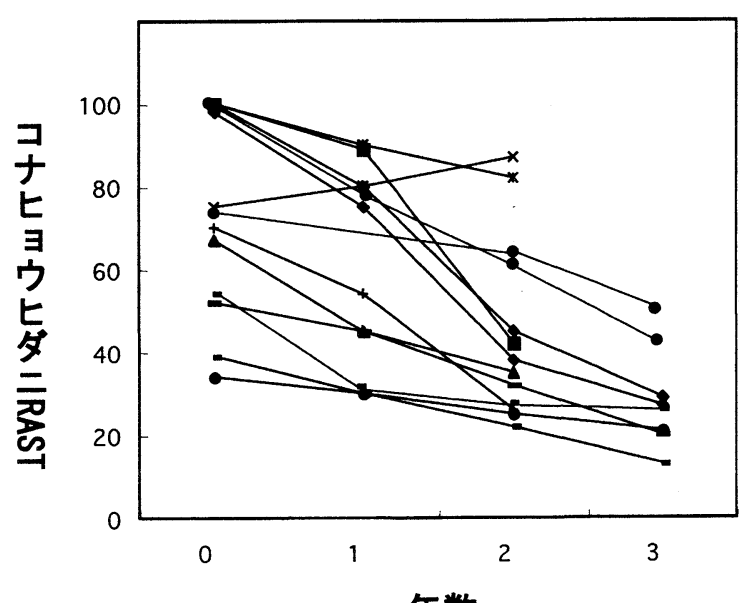

年数

\section{非軽快群}

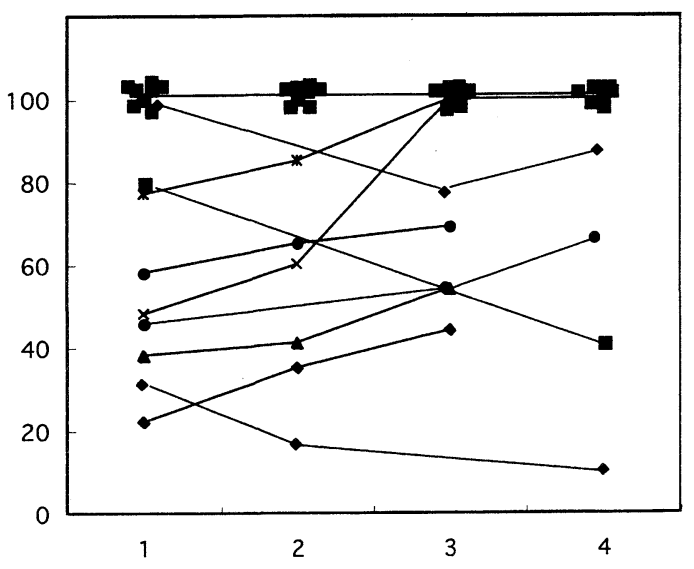

年数

図 3. 気管支喘息患者の特異 $\lg E$ 値の変化 


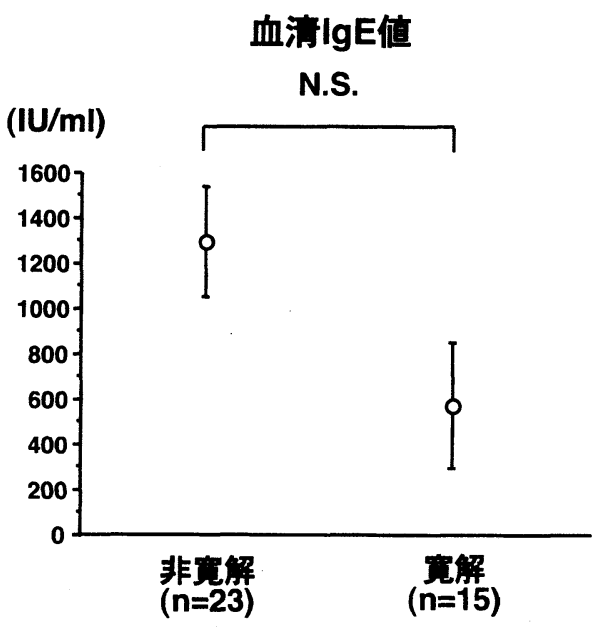

コナヒョウヒダニ特異 IgE値

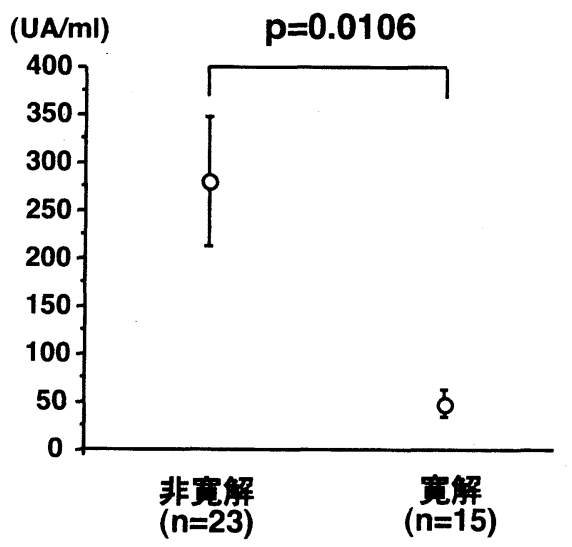

図4 非寛解・寛解ダニ感作喘息患者の IgE値

\section{IL-5産生細胞数}

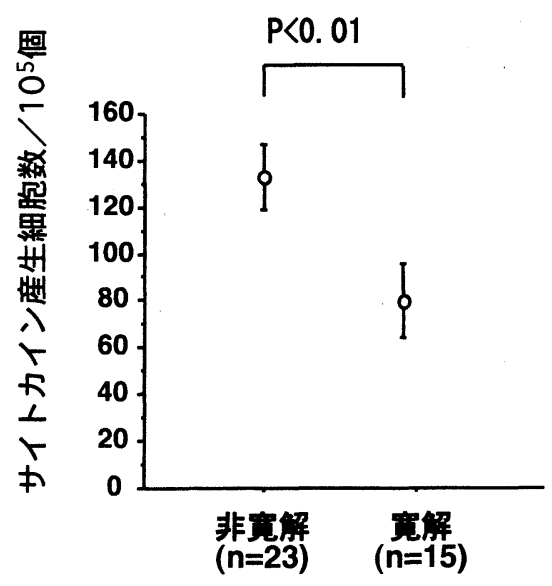

IL-10産生細胞数

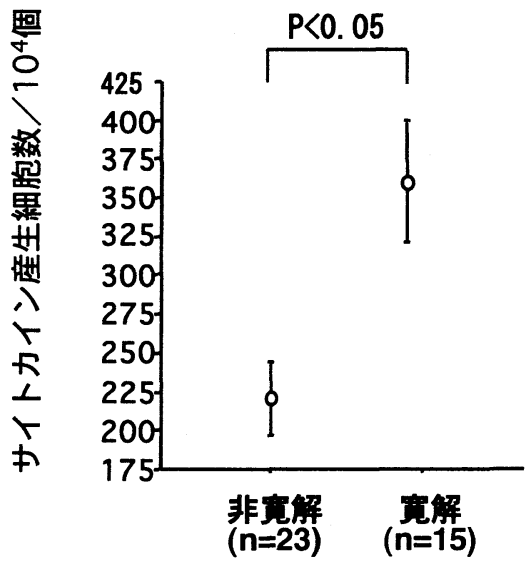

図 5. ダニ刺激による末梢血単核球中のサイトカイン産生細胞数

寛解におけるIL-10の位置づけ

ではこのTh2 サイトカインの低下はどのような機序 で誘導されているのだろうか? 健康人においてはアレ ルギ一反応の制御に抑制性 T細胞が関与していること が最近あきらかとなっている ${ }^{6)}$. 一方，気管支喘息の 寛解における制御性サイトカインの役割の報告は少な く, 最近Noma らが IL-10の役割を報告しているのみで ある ${ }^{7)}$. 我々の検討では寛解患者においては非寛解患 者に比してダニアレルゲン刺激による末梢血単核球中
のIL-10産生細胞数が有意に高值であった（図5). そ こで, IL-10が実際に寛解患者におけるダニアレルゲン に対する免疫反応を抑制しているかいなかを抗IL-10 レセプター抗体により IL-10の効果を阻害する実験で 確認した（図6）. 非寛解喘息患者末梢血単核球をダ二 アレルゲンで刺激するとリンパ球の増殖が誘導される. これに抗IL-10レセプター抗体を加えても増殖反応は 増強されない，寛解患者ではダニアレルゲン刺激のみ ではリンパ球増殖反応は誘導されない(寛容)。しか しながらこの系に抗IL-10レセプター抗体を加えると 
ダニアレルゲンに対する増殖反応が誘導された. 以上 から，寛解患者ではダニアレルゲン刺激により産生さ れるIL-10が免疫寛容に関与することが示唆される.

\section{喘息寛解と個体差}

小児気管支喘息の寛解率は $70 \%$ 内外といわれ，すべ ての喘息患者が寛解するわけではない，寛解において IL-10などの制御性サイトカイン産生能が重要である とするとそのIL-10 産生能の個体差が寛解獲得の有無 に関わっている可能性がある。 その機序はまだ明らか ではないが我々の予備的研究からは，寛解患者と非寛 解患者のIL-10遺伝子のプロモーター領域の遺伝子多 型に差異が認められている. 現在その多型と IL-10産生 能との関係を解析中である.このように, IL-10産生能 には個体差が存在すると考えられるが，すくなくとも 減感作療法といった大量のアレルゲン投与による治療 は大部分の患者で有効である. 現在までの報告では減 感作療法においてはIL-10産生も増強されることが報 告されている. そこで，抗原量やアレルゲン投与経路 の工夫により, 個体差をこえて IL-10産生を誘導するこ とが可能であると考えられる.
おわりに

喘息が臨床的寛解にあっても健康人に比べて気道好 酸球数が有意に多いことが報告されている ${ }^{8)}$. 我々の 解析でも寛解者のダ二刺激 IL-5 産生細胞数は非寛解よ りも低いが明らかに健康人よりは多いという結果で あった，すなわち，寛解患者であっても完全にTh2 反 応性が正常人のレベルになっているわけではない. 寛 解患者の再発はこれにより説明しうる可能性がある. 重要なのはTh2 サイトカインと IL-10などの制御性サ イトカインのバランスであり, そのバランスのシフト が寛解の有無や継続に大きく関与していると考えられ る. 今後そのバランスを変化させうる適切な免疫学的 治療法の開発が望まれる.

\section{文献}

1) Peroni DG, Chatzimichail A, Boner AL. Food allergy: what can be done to prevent progression to asthma? Ann Allergy Asthma Immunol 89 (6 Suppl 1) : 44-51, 2002.

2 ) Visser MJ, Brand PL, Boezen HM, et al. Clinical and immunologic factors associated with the presence

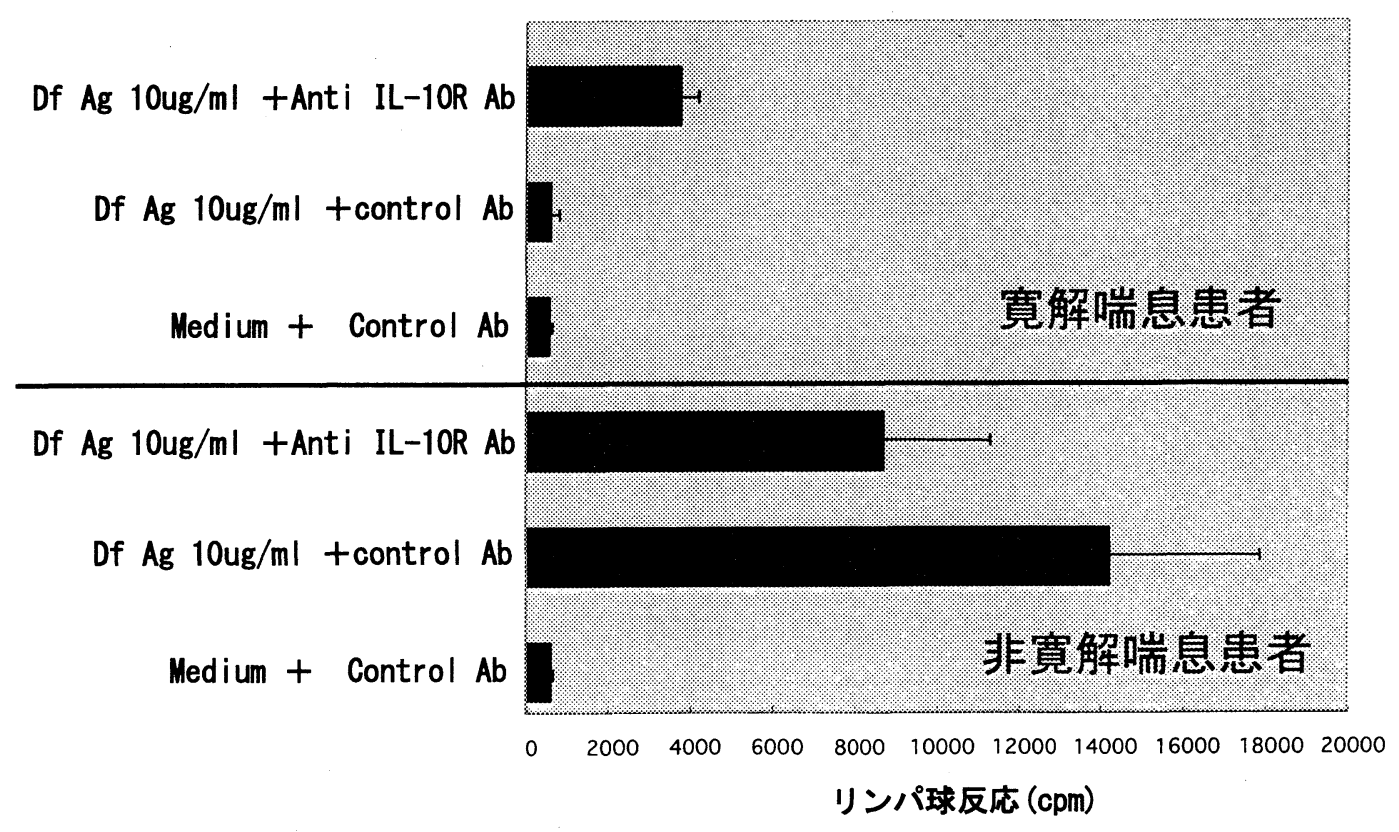

図 6. IL-10 中和による寛解患者リンパ球の増殖反応獲得 
or absence of airways hyper-responsiveness in childhood asthma. Clin Exp Allergy 32: 1278-84, 2002.

3) Illi S, von Mutius E, Lau S, et al. The pattern of atopic sensitization is associated with the development of asthma in childhood. J Allergy Clin Immunol 108: 709-14, 2001.

4 ) Cho SH, Stanciu LA, Holgate ST, et al. Increased interleukin-4, -5 and interferon-gamma in airway $\mathrm{CD} 4+$ and $\mathrm{CD} 8+\mathrm{T}$ cells in atopic asthma. Am J Respir Crit Care Med 2004 in press.

5 ) Bodtger U, Linneberg A. Remission of allergic rhinitis: An 8-year observational study. J Allergy Clin Immunol 114: 1384-8, 2004.
6) Akdis M, Verhagen J, Taylor A, et al. Immune responses in healthy and allergic individuals are characterized by a fine balance between allergenspecific T regulatory 1 and T helper 2 cells. J Exp Med 199: 1567-75, 2004.

7 ) Noma T, Sugawara Y, Ogawa N, et al. Dermatophagoidesinduced interleukin-10 production by peripheral blood lymphocytes from patients with asthma in remission. Pediatr Allergy Immunol 15: 459-68, 2004.

8) Warke TJ, Fitch PS, Brown V, et al. Outgrown asthma does not mean no airways inflammation. Eur Respir J 19: 284-7, 2002. 